\title{
PERLINDUNGAN HUKUM TERHADAP BANK BILA TERJADI KREDIT MACET OLEH DEBITOR PENANAM MODAL ASING
}

\author{
Hendera \\ Bank Maspion Cabang Mangga Dua Jakarta \\ Jalan Mangga Dua Raya Blok E4 No.1 \\ Ancol, Pademangan, Jakarta Utara 10730 \\ Email: hendera_porsche@yahoo.com
}

\begin{abstract}
Foreign Investment Company or better known as PMA is considered to have a proven competence to ensure its business along supported by a good capital structure, a bureaucratic procedure mechanism that must be passed by a foreign investment to run a company in Indonesia as an advantage, making the company selective, so banking industry considers a it to be potentials' as a target market in the distribution of credit facilities.

Credit Facility Distribution to Foreign Investment Company has a high risk if incase non-performing loan happen, therefore the status of foreign citizenship owner become shield from legal protection of the bank. Due on those cases, the author analyze the following issue: 1) What are the factors that causes non-performing loan in credit facility distribution by the foreign investment company? 2) What are the risks of the bank in the event of a non-performing loan y the foreign investment company? 3) How is the legal protection against bank in case of a non-performing loan occurs by the foreign investment company?

The research method used for this research is empirical theory with sociological approach, case study in Bank Maspion, Mangga Dua Branch, Jakarta. The conclusion is credit facility distribution to a foreign investment company is there is no special legal regulation that regulates the protection of the Bank as a creditor in case of a non-performing loan from foreign investors. So, the government is expected to make a constitution of legal protection against bank to assure a strong legal certainty. It will also help support banking industry to advance the nation's economy.
\end{abstract}

Key words: legal protection of bank, non-performing loan, foreign investment debitors

\begin{abstract}
Abstrak
Perusahaan penanam modal asing atau yang lebih dikenal dengan istilah PMA dianggap memiliki kompetensi yang telah teruji untuk menjamin kelangsungan usahanya serta didukung oleh struktur permodalan yang baik, mekanisme prosedur birokrasi yang harus dilalui sebuah perusahaan penanam modal asing untuk dapat menjalankan usahanya di Indonesia dianggap sebagai keuntungan bagi industri perbankan dikarenakan proses tersebut akan membuat perusahaan penanam modal asing yang ada bersifat selektif, sehingga industri perbankan memandang perusahaan penanam modal asing (PMA) sangat potensial untuk dijadikan pasar sasaran dalam penyaluran fasilitas kredit.

Penyaluran fasilitas kredit kepada debitor penanam modal asing (PMA) juga memiliki resiko yang besar terutama apabila terjadi kredit macet dalam penyaluran kredit tersebut, status kewarganegaraan asing pemilik usaha menjadikan aspek perlindungan hukum terhadap Bank selaku Kreditor memiliki posisi yang kurang baik, berdasarkan latar belakang tersebut penulis
\end{abstract}


mebatasi permasalahan: 1) Apa yang menjadi faktor-faktor terjadinya kredit macet dalam penyaluran kredit oleh perbankan kepada Debitor penanam modal asing? 2) Bagaimana resiko Bank bila terjadi kredit macet atas debitor penanam modal asing? 3) Bagaimana upaya perlindungan hukum terhadap Bank bila terjadi kredit macet pada kredit yang disalurkan pada penanam modal asing?.

Metode Penelitian yang digunakan dalam penulisan jurnal hasil penelitian ini adalah penelitian empiris dengan pendekatan sosiologi hukum (sosio legal research), dengan studi kasus di Bank Maspion cabang Mangga Dua Jakarta, hasil penelitian dapat disimpulkan bahwa dalam penyaluran fasilitas kredit oleh Bank kepada debitor penanam modal asing (PMA), belum terdapat aturan hukum yang bersifat khusus yang mengatur perlindungan terhadap Bank selaku kreditor apabila terjadi kredit macet dari debitor penanam modal asing, maka diharapkan pemerintah dapat segera melakukan membuat Undang-undang yang mengatur perlindungan terhadap Bank selaku kreditor bila terjadi kredit macet dengan debitor penanam modal asing sehingga dapat memberikan kepastian hukum yang kuat dan seimbang dalam rangka mendukung industri perbankan dalam memajukan perekonomian bangsa.

Kata kunci: perlindungan hukum terhadap bank, kredit macet, debitor penanam modal asing

\section{Latar Belakang}

Lembaga keuangan perbankan merupakan sektor yang memiliki peranan sangat penting dalam mendukung kemajuan perekonomian suatu negara. Bank sebagai lembaga keuangan yang memiliki peranan menghimpun serta menyalurkan dana dari masyarakat yang memberikan kontribusi vital bagi kemajuan dunia usaha baik ekonomi mikro maupun makro.

Secara faktual mengenai penyaluran fasilitas kredit dari bank kepada perusahaan yang sahamnya dimiliki oleh pemodal asing (PMA) diperlukan persyaratan-persyaratan dan berbagai ketentuan yang harus dipenuhi. Dasar hukum bagi perusahaan penanaman modal asing untuk dapat menjalankan usaha di Indonesia diatur dalam Undang-undang nomor 1 Tahun 1967 Tentang Penanaman Modal Asing telah terdaftar di dalam
Lembaran Negara Republik Indonesia Tahun 1967 nomor 1.

Phillipus M Hadjon dalam bukunya yang berjudul Perlindungan Hukum Bagi Rakyat di Indonesia berpendapat bahwa perlindungan hukum bagi rakyat sebagai tindakan pemerintah yang bersifat preventif dan represif ${ }^{1}$.

Perlindungan hukum merupakan sebuah usaha untuk melindungi hakekat individu dalam hidup bermasyarakat, dimana kebijakan yang dibuat oleh pemerintah selaku penguasa akan menjadi sumber hukum bagi masyarakatnya serta menjadi hukum positif dalam menjalani kehidupan sehari-hari. Pada prinsipnya perlindungan hukum merupakan sebuah upaya penguasa dalam melindungi hak-hak dasar individu yang menekankan pada pencegahan dan upaya bagi setiap masyarakat untuk mengakses kembali hak-haknya yang hilang.

1 Phillipus M. Hadjon, Perlindungan Hukum Bagi Rakyat Indonesia, (Surabaya: Bina Ilmu, 1987), hlm. 2. 
Adam Smith

(1723-1790) memperkenalkan pandangan mengenai perekonomian bebas dan merupakan pencetus teori ekonomi liberal yang berbasis pada perdagangan bebas antar negara berpendapat bahwa suatu negara dapat mencapai kemakmuran dengan cara perluasan perdagangan dengan negara lain. Adam Smith merupakan salah satu tokoh yang sangat mendukung perdagangan bebas antar negara dikarenakan dia berpendapat bahwa kemakmuran suatu negara dapat diukur dari kemampuan setiap masyarakat dalam meningkatkan penghasilan melalui produktifitas dan kerja keras. ${ }^{2}$

Raymond Vernon dan Charles P. Kindleberger adalah pelopor dari teori penanaman modal yang berpendapat bahwa kegiatan penanaman modal dapat membawa pengaruh pada perkembangan dan modernisasi ekonomi negara penerima modal dan proses tersebut dapat dilihat pada gejala perkembangan dan pertumbuhan ekonomi dunia dan mekanisme pasar yang dapat berlangsung baik dengan atau tanpa pengaturan dan fasilitas negara penerima modal. $^{3}$

Penanam modal asing adalah semua pihak yang melakukan penanaman modal di wilayah negara Republik Indonesia baik perseorangan maupun badan hukum ${ }^{4}$. Penanaman modal asing melakukan usaha di wilayah negara Republik Indonesia yang dilakukan oleh pemodal asing dengan cara berpatungan dengan pengusaha dalam negeri maupun sepenuhnya menggunakan modal sendiri. ${ }^{5}$

Berdasarkan ketentuan hukum yang berlaku di Indonesia bahwa setiap penanam modal asing yang ingin melakukan investasi di Indonesia diwajibkan dalam bentuk badan hukum berupa Perseroan Terbatas (PT). Hal ini ditegaskan dalam Undang-Undang Nomor 25 Tahun 2007 Tentang Penanaman Modal dan telah terdaftar di Lembaran Negara Republik Indonesia Tahun 2007 nomor 67, Pasal 5 ayat (2) yang berbunyi':

"Penanaman modal asing wajib dalam bentuk perseroan terbatas berdasarkan hukum Indonesia dan berkedudukan di dalam wilayah negara Republik Indonesia, kecuali ditentukan lain oleh undang-undang."

Selain memiliki kontribusi yang besar dalam memajukan perekonomian suatu Negara pada umumnya serta sebagai penyumbang laba pada sektor perbankan khususnya, penyaluran kredit kepada perusahaan penanam modal asing juga memiliki resiko yang cukup besar bila dalam penyaluran fasilitas kredit kepada badan usaha yang sahamnya dimiliki oleh warga negara asing (PMA) oleh sektor

2 Rahardja Pratama dan Mandala Manurung, Suatu Pengantar Teori Ekonomi Makro, (Jakarta: Lembaga Penerbit Fakultas Ekonomi Universitas Indonesia, 2014), hlm. 1.

3 Ilmar Aminudin, Hukum Penanaman Modal di Indonesia, (Jakarta: Kencana, 2010), hlm. 52.

4 Pasal 1 angka 6 Undang-undang Nomor 25 tahun 2007 tentang Penanaman Modal.

5 Ibid., Pasal 1 angka 3.

6 Ibid., Pasal 5 Ayat (2). 
perbankan ternyata mengalami gagal bayar atau dalam hal ini terjadi kredit macet dalam penyaluran kredit kepada debitor penanam modal asing.

Berdasarkan latar belakang yang telah diuraikan dalam penelitian ini, penulis merumuskan permasalahan sebagai berikut:

1. Apa yang menjadi faktor-faktor terjadinya kredit macet dalam penyaluran kredit oleh perbankan kepada Debitor penanam modal asing?

2. Bagaimana resiko Bank bila terjadi kredit macet atas debitor penanam modal asing?

3. Bagaimana upaya perlindungan hukum terhadap Bank bila terjadi kredit macet pada kredit yang disalurkan pada penanam modal asing?

Penelitian ini adalah jenis penelitian empiris dimana, penelitian ini hendak mengkaji mengenai perlindungan hukum terhadap Bank bila terjadi kredit macet dengan debitor penanam modal asing dengan memperhatikan faktor-faktor penyebab terjadinya kredit macet serta langkah-langkah pencegahan yang dilakukan jika terjadi kredit macet dengan debitor penanam modal asing agar Bank terlindung baik secara hukum dan terlindung dari potensi kerugian.

Pendekatan yang dilakukan peneliti menggunakan pendekatan sosiologi hukum (sosio legal research) yaitu melakukan analisis terhadap hubungan timbal balik peraturan hukum yang ada dengan kejadian faktual maupun gejala sosial, data-data yang didapatkan dari hasil diskusi dan wawancara dengan responden dalam hal ini adalah pihak terkait di Bank Maspion dan debitor yang mengalami kredit macet, baik secara tertulis maupun lisan sehingga didapat hasil pengumpulan data yang berkualitas dilapangan kemudian penulis menganalisis terhadap datadata dan kejadian faktual yang terjadi guna menjawab permasalahan penelitian.

\section{Pembahasan}

Besarnya penerimaan laba oleh sektor perbankan sebagai hasil usaha penyaluran kredit kepada debitor penanam modal asing (PMA) juga diimbangi dengan berbagai jenis resiko yang diterima oleh sektor perbankan, oleh karena itu sektor perbankan memerlukan analisis yang lebih mendalam untuk dapat melakukan tindakan pencegahan terhadap kredit macet, mengenali faktor-faktor yang menjadi penyebab terjadinya kredit macet, serta memahami cara penyelesaian bila terdapat kredit macet dengan debitor penanam modal asing sehingga perlindungan terhadap Bank sebagai kreditor dari kerugian maupun dari resiko hukum dapat terjamin dengan baik.

\section{A. Perkembangan PT. Bank Maspion. Tbk di Indonesia}

PT. Bank Maspion Indonesia Tbk atau lebih dikenal dengan Bank Maspion telah berdiri beroperasi pada tanggal 31 Agustus 1990 merupakan Bank yang berpusat di Surabaya. Saat ini Bank Maspion merupakan Bank dengan asset lebih dari Rp 5.000.000.000.000,- (lima triliun rupiah). 
Bank Maspion memiliki fokus pemberian kredit kepada bidang perdagangan dan industri, penggolongan debitur berdasarkan sektor ekonomi yang terbesar disalurkan kepada perdagangan besar dan eceran sebesar yang disusul dengan sektor industri pengolahan serta kredit konsumtif berupa kredit kepemilikan rumah.

Kebijakan yang dibuat oleh Bank Maspion, yang menjadikan perusahaan penanam modal asing (PMA) sebagai pasar sasaran dalam pemberian kredit sejalan dengan teori kebebasan (liberal) yang di gagas oleh Adam smith (1723 - 1790) yang memperkenalkan pandangan mengenai perekonomian bebas dan merupakan pencetus teori ekonomi liberal yang berbasis pada perdagangan bebas antar negara dimana Adam Smith berpendapat bahwa suatu negara dapat mencapai kemakmuran dengan cara perluasan perdagangan dengan negara lain? ${ }^{7}$.
Berikut merupakan komposisi penyaluran kredit antara pengusaha dalam negeri (lokal) dengan perusahaan penanam modal asing di PT. Bank Maspion Indonesia Tbk, tersaji dalam Gambar 1 berikut:

PT. Bintang Mas Asia merupakan salah satu perusahaan penanam modal asing yang mendapatkan fasilitas kredit dari PT. Bank Maspion Indonesia Tbk yang digunakan untuk fasilitas modal kerja revolving berupa pinjaman rekening koran guna kebutuhan modal kerja serta fasilitas kredit investasi yang bertujuan untuk pembelian gudang.

\section{B. Implikasi Yuridis Terjadinya Kredit Macet oleh Debitor Penanam Modal Asing}

Mekanisme penyaluran fasilitas kredit yang dilakukan oleh Bank pada umumnya memiliki persamaan dikarenakan adanya ketentuan umum yang mengatur mengenai

\section{Gambar 1. Persentase Debitur PMA dan PMDN Bank Maspion 2015}

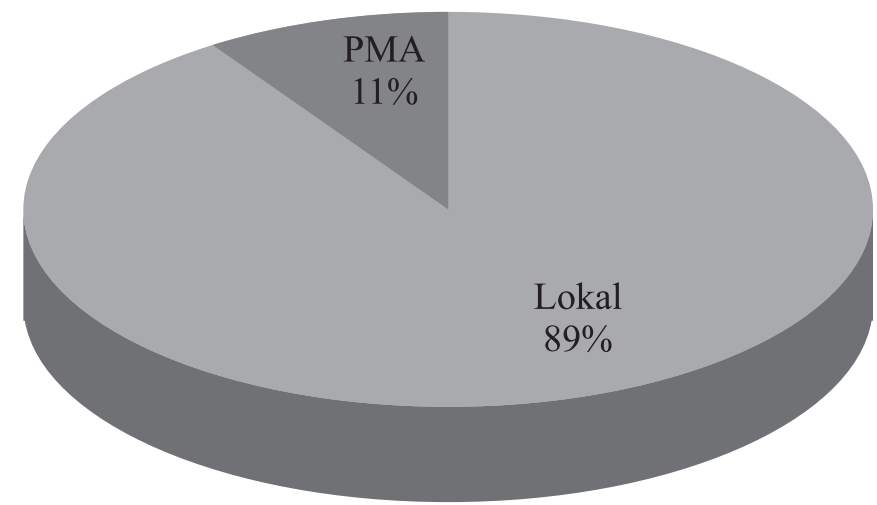

Sumber: $\quad$ Laporan Keuangan Bank Maspion Tahun 2015

7 Rahardja Pratama dan Mandala Manurung, Suatu Pengantar Teori Ekonomi Makro, (Jakarta: Lembaga Penerbit Fakultas Ekonomi Universitas Indonesia, 2014), hlm. 1. 
konsep analisa kelayakan terhadap debitor dengan menggunakan analisa prinsip $5 \mathrm{C}$ yang terdiri dari ${ }^{8}$ :

1. Character (Karakter)

2. Capacity (Kemampuan)

3. Capital (Permodalan)

4. Condition (Situasi /Kondisi)

5. Collateral (Jaminan)

Character atau karakter merupakan analisa terhadap watak atau kepribadian calon debitor. Capacity atau kapasitas merupakan analisa yang menggambarkan kemampuan bayar calon debitor dalam memenuhi kewajibannya terhadap Bank selaku kreditor. Capital merupakan aspek penilaian berdasarkan kecukupan permodalan debitor. Condition atau kondisi merupakan aspek yang bersifat dinamis, aspek ini menilai kelayakan usaha berdasarkan perkembangan dunia usaha saat ini, kondisi-kondisi ekonomi, sosial, dan politik dimasa kini dan masa yang akan datang menjadi bahan pertimbangan dalam penyaluran fasilitas kredit. Collateral atau jaminan merupakan aspek terpenting dikarenakan agunan second way out dalam penyelesaian kredit bermasalah.

PT. Bank Maspion Indonesia Tbk sangat konservatif dalam penilaian suatu agunan yang dijadikan jaminan kredit, hal ini diperlukan sebagai langkah mitigasi dalam perlindungan terhadap Bank dikarenakan hubungan dengan debitor dapat menimbulkan permasalahan apabila faktor jaminan dinilai lemah atau tidak mengcover dari nilai kredit yang diberikan. Melalui analisa 5C kemampuan bayar debitor dapat terlihat melalui kelima faktor tersebut.

Bank Maspion merupakan Bank yang memilih untuk memberikan porsi terbesar dalam fasilitas kredit kepada bidang perdagangan dan industri, fasilitas kredit tersebut diberikan baik kepada pengusaha lokal maupun penanam modal asing (PMA) dengan tetap memperhatikan prinsip kehatihatian dalam penyaluran kredit ${ }^{9}$. Salah satu debitor perusahaan penanam modal asing yang memperoleh fasilitas kredit dari PT. Bank Maspion Indonesia Tbk adalah PT. Bintang Mas Asia.

PT. Bintang Mas Asia sebelumnya merupakan usaha perorangan yang beroperasi sejak tahun 2010 dengan key person Lin Shifang yang bergerak dibidang perdagangan besar alas kaki seperti sandal dan sepatu berbahan dasar karet, barang dagangan didapatkan dengan cara mendatangkan secara langsung dari negara lain yaitu China (import).

Seiring dengan kebutuhan usaha yang berkembang dengan pesat, pada bulan februari 2013 PT. Bintang Mas Asia mendapatkan pengesahan sebagai badan hukum Perseroan Terbatas (PT). Seluruh kepemilikan dan kepengurusan dalam PT. Bintang Mas Asia dimiliki oleh warga negara asing yaitu China.

8 Banker Association for Risk Management, dan Lembaga Sertifikasi Profesi Perbankan, Modul Uji Kompetensi Profesi Bankir Bidang Managemen Resiko Level 1-edisi 4, (Jakarta: Banker Association For Risk Managemen, 2013), hlm. II-9.

9 Pasal 25 Undang-undang Nomor 23 tahun 1999 tentang Bank Indonesia. 
Dengan demikian PT. Bintang Mas Asia termasuk dalam kategori perusahaan penanam modal asing (PMA) sebagaimana yang dimaksudkan dalam Undang-Undang Nomor 25 Tahun 2007 Tentang Penanaman Modal. ${ }^{10}$

PT. Bintang Mas Asia (debitor penanam modal asing) mengajukan permohonan kredit kepada PT. Bank Maspion Indonesia Tbk tertanggal 26 November 2013 dengan nomor 363/MK/J8/MD-JKT/XI/2013 berupa kredit investasi sebesar Rp. 3.000.000.000,-(tiga milyar rupiah), jangka waktu 60 bulan yang akan digunakan untuk pembelian 1 (satu) unit gudang seluas 216 meter persegi yang terletak di lodan center, Jalan raya lodan 2 blok H nomor 9, Kelurahan Ancol, Kecamatan Pademangan, Jakarta Utara dan kredit modal kerja yaitu pinjaman rekening koran (PRK) sebesar Rp. 2.000.000.000,- (dua milyar rupiah) yang akan digunakan untuk membiayai persediaan barang dagangan dan piutang usaha PT. Bintang Mas Asia yang bergerak dibidang perdagangan besar alas kaki.

Berdasarkan analisa yang dilakukan oleh Bank terhadap kelayakan usaha PT. Bintang Mas Asia dengan menggunakan prinsip analisa 5C yang terdiri dari character (karakter), capacity (kemampuan), capital (permodalan), condition (situasi/kondisi), collateral (jaminan), hasil dari komite kredit Bank Maspion menyetujui permohonan kredit PT. Bintang Mas Asia.
Pemberian fasilitas kredit kepada PT. Bintang Mas Asia (debitor penanam modal asing) dilakukan pada tanggal 14 Februari 2014 dengan fasilitas berupa Pinjaman Rekening Koran (PRK) sebesar Rp. 2.000.000.000,- (dua milyar rupiah) bertujuan untuk membiayai arus kas usaha debitor berupa pembiayaan atas persediaan barang dagangan dan piutang usaha debitor. Sedangkan fasilitas Kredit Investasi sebesar Rp. 3.000.000.000,- (tiga milyar rupiah) bertujuan untuk pembelian 1 (satu) unit Tanah dan Bangunan (gudang) yang akan digunakan untuk kegiatan usaha debitor sebagai tempat penyimpanan barang dagangan debitor yang berupa alas kaki sendal.

Dengan demikian total fasilitas kredit yang diterima PT. Bintang Mas Asia dari PT. Bank Maspion indonesia Tbk adalah sebesar Rp. 5.000.000.000,- (lima milyar rupiah). Proses pengikatan kredit dilakukan secara notariil dengan menggunakan notaris yang ditunjuk oleh Bank Maspion.

Bank Indonesia membagi tingkat kolektibilitas kredit atau kualitas kredit menjadi 5 (lima) kategori yaitu ${ }^{11}$ :

Kolektibilitas 1 (lancar) adalah kategori debitor dengan pembayaran lancar, debitor dalam memenuhi kewajibannya terhadap Bank selama ini tidak terdapat keterlambatan pembayaran baik pokok pinjaman maupun bunga. Debitor dengan kategori kolektibilitas

10 Pasal 1 angka 6 Undang-undang Nomor 25 tahun 2007 tentang Penanaman Modal.

11 Pasal 12 Ayat 3 Peraturan Bank Indonesia Nomor 14/15/PBI/2012 tentang Penilaian Kualitas Aset Bank Umum. 
1 adalah debitor yang menjadi pasar sasaran dalam pemberian kredit dikarenakan debitor memiliki sejarah kredit yang baik.

Kolektibilitas 2 (dalam perhatian khusus) adalah debitor dengan sejarah kredit yang memiliki tunggakan baik pokok maupun bunga pinjaman dengan keterlambatan sampai dengan 90 (sembilan puluh) hari. Bank selaku kreditor harus memiliki pertimbangan khusus untuk memberikan fasilitas bagi debitor dengan tingkat kolektibilitas 2, analisa mengenai sebab keterlambatan pembayaran terhadap kreditor sebelumnya harus dilakukan secara mendalam agar tidak terjadi kredit macet dikemudian hari. Jika keterlambatan pembayaran disebabkan oleh repayment capacity maka Bank harus melakukan pertimbangan kembali dalam pemberian fasilitas kredit kepada debitor yang bersangkutan di karenakan risiko kegagalan dalam memenuhi kewajiban debitor sangat besar.

Kolektibilitas 3 (kurang lancar) yaitu adanya tunggakan atas kewajiban pembayaran baik pokok maupun bunga atas fasilitas kredit yang diterima sampai dengan 120 (seratus dua puluh) hari. Calon debitor dengan status kolektibilitas kurang lancar umumnya sulit untuk mendapatkan fasilitas kredit dari Bank.

Kolektibilitas 4 (diragukan) yaitu apabila terdapat tunggakan atas kewajiban yang dilakukan debitor dengan jangka waktu sampai dengan 180 (seratus delapan puluh) hari.
Debitor dengan status diragukan merupakan debitor yang masuk dalam kategori memiliki risiko tinggi.

Kolektibilitas 5 (macet) adalah debitor dengan keterlambatan pembayaran diatas 180 (seratus delapan puluh) hari. Debitor dengan kolektibilitas 5 merupakan debitor yang sangat dihindari oleh Bank dalam pemberian kredit dikarenakan dapat menimbulkan angka kredit macet bagi Bank yang akan berpengaruh pada tingkat kesehatan Bank.

Informasi mengenai kualitas kredit debitor tersaji dalam sistem informasi debitor (SID) atau yang lebih dikenal dengan istilah BI checking.

Dalam sisi perbankan, penyebab terjadinya kegagalan dalam pemberian kredit yang menjadi faktor terjadinya kredit macet dapat diuraikan sebagai berikut ${ }^{12}$ :

1. Adanya kepentingan pribadi atas kredit yang diberikan.

2. Tidak mempertimbangkan arus kas pengembalian.

3. Pemberian kredit dilakukan dengan menyimpangi prinsip kredit sehat.

4. Syarat proses pengelolaan berupa kebijakan dan prosedur kredit yang baik tidak tersedia.

5. Tidak lengkapnya informasi yang didapatkan.

6. Lambatnya tindakan likuidasi yang dilakukan Kreditor.

12 Banker Association for Risk Management, dan Lembaga Sertifikasi Profesi Perbankan, Modul Uji Kompetensi Profesi Bankir Bidang Managemen Resiko Level 1-edisi 4, (Jakarta: Banker Association For Risk Managemen, 2013), hlm. II-17 dan II-18. 
7. Menganggap mudah sebuah permasalahan.

8. Konsistensi pengawasan kredit tidak tersedia.

9. Tidak adanya kemampuan teknis.

10. Kurangnya keahlian melakukan seleksi atas resiko.

11. Kredit yang diberikan dilakukan secara berlebihan.

12. Tingginya tingkat persaingan usaha.

Sedangkan dari sisi debitor, kredit macet disebabkan oleh faktor:

1. Faktor Internal

Faktor Internal merupakan faktor terjadinya kredit macet disebabkan oleh kondisi internal debitor.

2. Faktor eksternal

Faktor Eksternal merupakan faktor terjadinya kredit macet disebabkan oleh pihak luar.

Dalam studi kasus yang terjadi, PT. Bintang Mas Asia mengalami kredit macet disebabkan oleh tekanan persaingan usaha yang merupakan faktor eksternal.

Tingginya persaingan di bidang perdagangan alas kaki menjadikan PT. Bintang Mas Asia harus mengurangi keuntungan perusahaan ditambah minimnya angka penjualan akibat lesunya sektor ekonomi Indonesia akhir-akhir ini menyebabkan efek yang sangat buruk bagi arus kas usaha.
C. Perlindungan Hukum terhadap Bank bila Terjadi Kredit Macet oleh Debitor Penanam Modal Asing

Angka kredit macet akan mempengaruhi tingkat kesehatan suatu Bank. Tingkat kesehatan Bank merupakan gambaran kondisi Bank berdasarkan hasil penilaian yang dilakukan terhadap risiko dan kinerja Bank ${ }^{13}$. Berdasarkan peraturan Bank Indonesia bahwa batas ambang maksimum untuk kredit bermasalah sebuah Bank (non performing loan) adalah lebih dari 5\% (lima persen) secara neto dari total kredit. ${ }^{14}$

Dengan demikian bagi Bank yang memiliki tingkat kredit macet diatas 5\% (lima persen) maka akan dikategorikan Bank yang tidak sehat, predikat ini dapat mempengaruhi bisnis Bank kedepan dikarenakan tingkat kepercayaan masyarakat terhadap Bank dengan kategori tidak sehat akan menurun. Penurunan tingkat kepercayaan masyarakat akan berimbas pada menurunnya jumlah dana pihak ketiga berupa tabungan, giro, maupun deposito yang dihimpun Bank dari masyarakat. Hal ini tentu merupakan sebuah kerugian bagi Bank dikarenakan kepercayaan memegang peranan yang sangat penting dalam industri Perbankan.

Tingkat kesehatan Bank yang sangat dipengaruhi oleh hasil penilaian kondisi Bank

13 Pasal 1 angka 4 Peraturan Bank Indonesia Nomor 13/1/PBI/2011 tentang Penilaian Tingkat Kesehatan Bank Umum.

14 Pasal 2 Ayat 2 Huruf g Peraturan Bank Indonesia Nomor 3/25/PBI/2001 tentang Penetapan Status Bank Dan Penyerahan Bank Kepada Badan Penyehatan Perbankan Nasional. 
terhadap risiko adalah unsur penting dalam menjaga kelangsungan bisnis Bank. Resiko adalah potensi terjadinya suatu peristiwa (events ) yang dapat menimbulkan kerugian Bank $^{15}$. Resiko dapat diartikan sebagai dampak negatif untuk mencapai tujuan, dalam industri perbankan terdapat 8 (delapan) jenis resiko yang telah ditetapkan dalam ketentuan Bank Indonesia No.5/8/PBI/2003 dan perubahannya No.11/25/PBI 2009 tentang Penerapan Manajemen Risiko Bagi Bank Umum, antara lain:

\section{Risiko Kredit}

Risiko Kredit adalah gagalnya debitor memenuhi kewajibannya yang berasal dari berbagai aktivitas fungsional Bank seperti perkreditan, treasuri, investasi, dan pembiayaan perdagangan.

2. Risiko Pasar

Risiko pasar adalah risiko yang timbul akibat dari adanya perubahan harga pasar pada posisi administratif termasuk didalamnya transaksi derivatif. Beberapa contoh dari risiko pasar antara lain disebabkan oleh perubahan harga komoditas, suku bunga, nilai tukar,dan harga saham.

\section{Risiko Likuiditas}

Risiko likuiditas timbul karena Bank gagal memenuhi kewajiban yang jatuh tempo dari sumber pendanaan arus kas dan atau dari asset likuid berkualitas tinggi yang dapat diagunkan, tanpa mengganggu kondisi keuangan Bank.

\section{Risiko Operasional}

Risiko operasional adalah risiko ketidakcakapan proses internal baik berupa kegagalan pada sistem yang digunakan maupun kesalahan yang dibuat oleh manusia serta kejadian-kejadian eksternal yang dapat mempengaruhi operasional Bank.

\section{Risiko Kepatuhan}

Merupakan risiko yang terjadi apabila Bank tidak mematuhi maupun melaksanakan ketentuan internal maupun perundangundangan yang berlaku.

\section{Risiko Hukum}

Resiko hukum ialah resiko akibat kelalaian Bank sehingga berdampak dengan adanya kelemahan dari aspek yuridis dalam menghadapi tuntutan dari pihak lain. Risiko ini disebabkan tidak tersedianya peraturan perundang-undangan yang mengakomodir kebutuhan Bank.

7. Risiko Reputasi

Adalah sebuah kejadian yang dapat menimbulkan persepsi negatif atau buruk terhadap Bank, sehingga berakibat pada menurunnya kepercayaan masyarakat maupun stakeholder.

\section{Risiko Strategis}

Risiko Strategis adalah risiko yang timbul akibat ketidaktepatan ataupun kekeliruan dalam pengambilan keputusan maupun pelaksanaan keputusan sehingga terjadi kegagalan dalam menyesuaikan dengan kebutuhan bisnis yang ada sehingga Bank 
tidak mampu untuk yumbuh dan bersaing diantara pemain sejenis dilapangan.

Dalam hal terjadinya kredit macet di Bank Maspion atas penyaluran kredit kepada debitor penanam modal asing yaitu PT. Bintang Mas Asia, risiko yang dihadapi Bank merupakan jenis risiko kredit dan risiko hukum.

Kegagalan PT. Bintang Mas Asia yang disebabkan oleh ketidakmampuan dalam memenuhi kewajibannya terhadap Bank adalah sebuah risiko dari kegiatan pemberian kredit yang ditanggung oleh Bank Maspion. Hal ini dikategorikan sebagai risiko kredit dikarenakan kerugian timbul karena kegagalan dari pihak lawan yaitu debitor PT. Bintang Mas Asia dalam memenuhi kewajibannya.

Akibat dari risiko kredit tersebut akan berdampak pada risiko hukum dikarenakan kedua belah pihak baik debitor mauapun kreditor akan berusaha mempertahankan haknya masing-masing yang akan berdampak pada risiko hukum yang dihadapi oleh Bank.

Terdapat kekosongan hukum, dimana tidak adanya aturan yang mengatur mengenai penanganan kredit macet dengan debitor penanam modal asing sehingga Bank selaku kreditor harus berupaya melindungi diri dalam aspek yuridis agar tidak terdapat kelemahan dalam menghadapi tuntutan hukum.
Manajemen Risiko adalah serangkaian prosedur dan metodelogi yang digunakan untuk mengidentifikasi, mengukur, mengetahui, memantau serta mengendalikan resiko yang timbul dari kegiatan usaha ${ }^{16}$.

Penetapan kebijakan dan prosedur mengenai manajemen risiko Bank umum sekurang-kurangnya berupa pengawasanpengawasan yang dilakukan oleh para pengurus Bank, adanya pendelegasian wewenang kepada pejabat terkait di internal Bank, dilakukannya pemisahan tugas dan tanggungjawab, dilakukannya pengawasan secara internal melalui audit, serta menjalankan ketentuan mengenal nasabah ${ }^{17}$ :

Selainmenjalankan kebijakan dan prosedur mengenai manajemen risiko Bank umum yang telah ditetapkan oleh Bank Indonesia, mitigasi risiko kredit juga dilakukan di Bank Maspion secara internal sebagai upaya agar Bank terlindung dari terjadinya kredit macet debitor penanam modal asing meliputi perlindungan terhadap Bank melalui langkah-langkah:

1. Menjalankan Prinsip Know Your Customer (KWCP)

Know your customer adalah prinsip yang diatur oleh Peraturan bank Indonesia sebagai sebuah upaya agar Bank mengetahui identitas nasabah,serta kegiatan usaha nasabah tersebut hal ini termasuk pelaporan terhadap transaksi yang mencurigakan ${ }^{18}$.

16 Pasal 1 Angka Peraturan Bank Indonesia Nomor 5/8/PBI/2003 tentang Penerapan Managemen Resiko Bagi Bank Umum

17 Pasal 11 Peraturan Bank Indonesia Nomor 3/10/PBI/2001 tentang Penerapan Prinsip Mengenal Nasabah (Know Your Customer Principles).

18 Ibid., Pasal 1 Angka 2. 
Bank selaku debitor dalam menjalankan prinsip know your customer wajib menerapkan:

a. Membuat kebijakan untuk setiap penerimaan nasabah.

b. Melakukan identifikasi terhadap nasabah.

c. Pemantauan terhadap transaksi nasabah.

d. Menjalankan prosedur manajemen risiko.

2. Menetapkan pasar sasaran penyaluran kredit

Penetapan pasar sasaran Bank Maspion yang hanya menyalurkan kredit untuk bidang perdagangan dan industri saja merupakan suatu langkah nyata guna mengendalikan risiko dari kegiatan penyaluran kredit di Bank Maspion.

Hal ini dilakukan guna menekan angka kredit macet dikarenakan pembiayaan kepada bidang perdagangan dan industri dianggap lebih aman dan minim akan spekulasi, sehingga potensi risiko terjadinya kredit macet dinilai lebih kecil.

3. Pembentukan divisi credit reviewer

Credit reviewer berfungsi sebagai filter dalam menyalurkan fasilitas kredit, credit reviewer melakukan analisa mendalam terhadap proposal kredit yang diajukan oleh calon debitor, memastikan Bank menjalankan analisa 5C dengan baik, serta mengeluarkan reviewer mengenai proposal kredit yang diajukan apakah termasuk dalam kategori kredit yang direkomendasikan atau tidak direkomendasikan untuk disetujui.

\section{Agunan kredit}

Agunan kredit yang dapat menjadi agunan pokok di Bank Maspion hanya berupa fix asset (tanah dan bangunan), hal ini dimaksudkan agar jaminan yang diberikan oleh debitor dapat mengcover seluruh plafond kredit debitor di Bank. Sehingga bila dikemudian hari terjadi kredit macet pada debitor tersebut, maka hak-hak Bank terlindungi dari potensi kerugian.

Jaminan berupa mesin, piutang dagang, dan stock barang hanya bersifat agunan tambahan yang tidak menambah cover ratio yang akan mempengaruhi plafond kredit yang dapat diberikan.

5. Nilai likuiditas jaminan kredit

Bank Maspion selaku kreditor melakukan penilaian terhadap agunan yang diberikan debitor, proses penilaian agunan dilakukan melalui appraisal internal dan appraisal independen (untuk plafond kredit dengan nilai diatas Rp.5.000.000.000,-). Terdapat 2 (dua) nilai dalam hasil penilaian appraisal yang meliputi:

\section{a. Nilai Pasar}

Nilai pasar merupakan nilai yang didapat berdasarkan perbandingan dengan nilai jual asset sejenis dilapangan pada saat penilaian dilakukan, umumnya nilai pasar berada diatas nilai jual obyek pajak (NJOP).

b. Nilai Likuiditas

Nilai likuiditas merupakan nilai jual cepat atas asset yang diagunkan. Nilai likuiditas yang ditentukan oleh Bank Maspion adalah $70 \%$ (tujuh puluh persen) dari nilai pasar yang dikeluarkan oleh appraisal.

Nilai likuiditas yang didapat dijadikan sebagai nilai dasar dalam menentukan batas 
kredit yang diberikan oleh Bank Maspion kepada debitor, disamping aspek analisa lain seperti mutasi rekening dan kinerja keuangan yang juga mempengaruhi besarnya batas kredit yang diterima debitor.

6. Nilai hak tanggungan

Standar nilai hak tanggungan yang dibebankan kepada debitor yang menerima fasilitas kredit di Bank Maspion ditetapkan melalui kebijakan manajemen adalah sebesar $120 \%$ (seratus dua puluh persen) dari nilai plafond yang diterima debitor. Hal ini bertujuan jika terjadi kredit macet atas fasilitas kredit yang disalurkan, maka biaya-biaya yang timbul akibat ketrlambatan pemenuhan kewajiban debitor serta biaya-biaya akibat penyelesaian kredit macet tersebut, dapat tercover dengan nilai hak tanggungan yang disepakati pada saat pengikatan kredit dilakukan.

7. Syarat kredit wajib bagi penanam modal asing

Penanam modal asing yang dapat menjadi debitor di Bank Maspion wajib memiliki perijinan lengkap. Debitor penanam modal asing harus memiliki izin dari Badan Koordinasi Penanaman Modal (BKPM) untuk menjalankan usahanya di Indonesia, wajib berbadan hukum Indonesia, serta seluruh pemilik dan pengurus memiliki izin tinggal dan izin kerja di Indonesia.

8. Perjanjian kredit dilakukan secara Notariil
Merupakan standar baku bagi Bank Maspion bahwa seluruh perjanjian kredit harus dilakukan secara notariil melalui Notaris rekanan Bank, hal ini dimaksudkan untuk mendapatkan kepastian hukum agar jika terjadi permasalahan dikemudian hari, Bank dapat mengakses kembali haknya.

9. Sertifikat hak tanggungan.

Proses pengikatan kredit di Bank Maspion selalu diiringi dengan pemasangan hak tanggungan atas jaminan yang diberikan, sehingga Bank lebih terlindungi dari segi hukum atas kemungkinan terjadinya kredit macet. Dengan adanya hak tanggungan yang diterbitkan atas nama Bank, maka jika terjadi kredit macet dikemudian hari,Bank tidak perlu melalui mekanisme persidangan perdata terlebih dahulu untuk melakukan eksekusi atas jaminan kredit yang ada. Dengan adanya sertifikat hak tanggungan maka Bank hanya mendaftarkan sita eksekusi saja ke Pengadilan dikarenakan didalam sertifikat hak tanggungan terdapat kekuatan eksekutorial yang sama dengan pengadilan yang telah memiliki kekuatan hukum yang tetap. ${ }^{19}$

10. Pemantauan berkala

Bank Maspion melakukan kunjungan berkala untuk seluruh debitor yang mendapatkan fasilitas kredit di Bank. Kunjungan ini dimaksudkan jika terjadi kemungkinan risiko atas usaha debitor, maka Bank dapat melakukan langkah-langkah pencegahan.

19 Pasal 14 Ayat (2) Undang-undang Republik Indonesia Nomor 4 Tahun 1996 tentang Hak Tangggungan Atas Tanah Beserta Benda-Benda Yang Berkaitan Dengan Tanah. 
Kredit bermasalah dapat dilakukan penanganannya dengan tindakan-tindakan sebagai berikut ${ }^{20}$ :

\section{a. Rescheduling}

Yaitu memperpanjang jangka waktu kredit maupun angsuran sehingga akan memperpanjang waktu kredit serta memperkecil jumlah kewajiban.

\section{b. Reconditioning}

Upaya penanganan kredit bermasalah dengan cara reconditioning dilakukan dengan merubah persyaratan, seperti:

1. Menjadikan bunga sebagai hutang pokok (kapitalisasi bunga).

2. Penundaan pembayaran bunga hingga waktu tertentu.

3. Penurunan suku bunga.

4. Pembebasan bunga.

c. Restructuring

Yaitu Bank melakukan penambahan terhadap plafond kredit milik debitor dengan keyakinan bahwa penambahan fasilitas tersebut akan berdampak positif bagi usaha debitor.

d. Kombinasi

Yaitu sebuah perpaduan dari restructuring, rescheduling, reconditioning.

e. Penyitaan Jaminan

Merupakan alternatif terakhir bagi Bank dalam menghadapi permasalahan kredit macet yaitu dengan menjadikan asset yang dijaminkan sebagai media pelunasan atas sisa kewajiban debitor kepada Bank.
Selain regulasi mengenai penyelesaian kredit macet yang telah diatur dalam peraturan Bank Indonesia, Bank pada umumnya telah memiliki prosedur standard tersendiri guna melindungi Bank dari tuntutan hukum serta potensi kerugian yang disebabkan oleh kredit macet.

Dengan memperhatikan ketentuan Bank Indonesia dan Otoritas Jasa Keuangan, Bank Maspion memiliki standard operasional prosedur (SOP) dalam penyelesaian kredit macet, yang dapat diuraikan sebagai berikut:

\section{Teguran lisan}

Merupakan upaya persuasif, teguran bersifat lisan diberikan segera setelah debitor mengalami keterlambatan sekurangkurangnya 1 (satu) hari dari tanggal jatuh tempo namun kewajiban belum dilakukan oleh debitor.

\section{Surat peringatan 1}

Pemberian surat peringatan 1 (satu) dilakukan pada saat debitor tidak dapat memenuhi kewajibannya berupa angsuran pokok maupun bunga kepada Bank yang diberikan secara tertulis, pada tahap ini debitor berapa pada posisi likuiditas kredit kolektibilitas 2 (dua).

3. Surat peringatan 2

Surat Peringatan 2 (dua) diberikan dengan jangka waktu 1 (satu) minggu dari diterbitkannya surat peringatan 1 (satu).

4. Surat peringatan 3

Surat peringatan 3 (tiga) diberikan apabila 
tidak ada upaya nasabah untuk menyelesaikan kewajibannya terhadap Bank dari waktu diterbitkannya surat peringatan 2 (dua).

\section{Somasi 1}

Somasi 1 (satu) dilakukan pada posisi likuiditas debitor berada di tingkat kolektibilitas 3 (tiga).

6. Somasi 2

Somasi 2 (dua) diberikan dengan jangka waktu 1 (satu) minggu dari dikeluarkannya somasi 1 (satu).

7. Somasi 3

Somasi 3 (tiga) merupakan somasi terakhir, yang diberikan pihak Bank kepada debitor, diberikan dengan jangka waktu 1 (satu) minggu dari somasi 2 (dua).

8. Surat pengacara rekanan

Surat pengacara rekanan yang dikeluarkan kepada debitor berisi bahwa Bank selaku kreditor telah bersiap untuk melakukan langkah hukum dalam mendapatkan haknya kembali.

9. Permohonan sita eksekusi ke pengadilan (aanmaning)

Permohonan sita eksekusi dapat langsung dilakukan oleh Bank, Bank dengan hak tanggungan yang ada langsung dapat mengajukan permohonan sita eksekusi atas jaminan tersebut kepengadilan dikarenakan hak tersebut telah diatur dalam UndangUndang hak tanggungan.

Phillipus M. Hadjon dalam bukunya yang berjudul Perlindungan Hukum Bagi Rakyat di Indonesia berpendapat bahwa perlindungan hukum bagi rakyat sebagai tindakan pemerintah yang bersifat preventif dan represif. ${ }^{21}$

1. Sarana perlindungan hukum preventif

Merupakan sebuah upaya pencegahan yang dilakukan pemerintah, sengan mendengarkan saran dan masukkan dari subyek hukum sebelum dibuatnya sebuah kebijakan sehingga terjadinya sengketa akan dapat diminimalisir bahkan di cegah.

Perlindungan hukum preventif memiliki peranan yang sangat penting guna menjaga ketertiban dalam bermasyarakat dan bernegara dikarenakan adanya suatu aturan yang jelas mengenai konsep kebebasan yang berlaku dalam masyaraka sehingga hak-hak setiap individu dapat dipahami dengan baik.

2. Sarana perlindungan hukum represif

Manfaat dari Perlindungan hukum represif ialah sebagai saran untuk mengakses kembali hak-hak yang hilang melalui penyelesaian sengketa. Penyelesaian sengketa melalui sarana pengadilan merupakan salah satu bentuk perlindungan hukum represif.

Prinsip perlindungan hukum baik berupa produk legislatif maupun yurisprudensi berpegangan pada hakekat hukum, sumbersumber hukum dan jenis hukum yang merupakan prinsip dari sebuah negara hukum. Tujuan dari negara hukum sangat berkaitan dengan adanya pengakuan serta upaya perlindungan terhadap hak-hak asasi manusia. ${ }^{22}$ 
Dalam segi perlindungan hukum terhadap pihak-pihak terkait, masing-masing pihak yang berkepentingan memiliki dasar hukum sendirisendiri untuk melindungi haknya masingmasing. Dari sisi pemerintah perlindungan berupa proses arbitrase internasional harus disepakati kedua belah pihak $^{23}$, merupakan bentuk perlindungan terhadap negara dari sengketa yang disebabkan perselisihan dengan penanam modal asing.

Jaminan tidak adanya nasionalisasi terhadap usaha yang dimiliki, perusahaan penanam modal asing memiliki kebebasan mentransfer dana keluar negeri, serta jaminan mendapatkan perlakuan yang sama dengan investor dalam negeri merupakan bentuk perlindungan terhadap penanam modal asing agar dapat menjalankan usahanya dengan nyaman dan memberikan kepastian hukum akan status perusahaan mereka di Indonesia, sehingga kelangsungan investasi dapat berjalan dengan baik.

Sedangkan perlindungan hukum terhadap Bank bila terjadi kredit macet dengan debitor penanam modal asing, belum memiliki dasar hukum yang mengaturnya sehingga Bank akan melakukan upaya penanggulangan risiko kredit macet secara sendiri-sendiri guna menghindari kerugian akibat penyaluran kredit kepada penanam modal asing dan menghindari gugatan hukum akibat penyaluran kredit kepada penanam modal asing.
Dalam upaya perlindungan hukum terhadap Bank dari kredit macet dengan debitor penanam modal asing, Bank Maspion sangat mengandalkan 2 (dua) hal yaitu perjanjian kredit dan pemasangan hak tanggungan.

Perjanjian kredit secara notariil oleh Bank Maspion merupakan perjanjian kredit yang baku digunakan kepada seluruh debitor Bank baik debitor lokal maupun debitor penanam modal asing, perjanjian kredit ini memuat seluruh penjelasan mengenai syarat dan ketentuan kredit, hak dan kewajiban Bank serta debitor hingga penyelesaian sengketa.

Perjanjian kredit yang dibuat oleh Bank Maspion dengan PT. Bintang Mas Asia selaku debitor penanam modal asing merupakan jenis perjanjian baku atau lebih dikenal dengan istilah standard contract. Perjanjian kredit dikategorikan sebagai perjanjian baku atau standard contract dikarenakan telah memenuhi unsur dibakukannya meliputi model, rumusan, dan ukuran dari perjanjian kredit yang dibuat ${ }^{24}$.

Penggunaan standard contract atau perjanjian baku dianggap dapat mengakomodir kepentingan Bank dan memiliki sifat efisien, efektif serta ekonomis. Dikarenakan dibuat secara sepihak oleh kreditor, sehingga debitor berada dalam posisi take it or leave it, Bank Maspion tidak memberikan kesempatan pada PT. Bintang Mas Asia untuk melakukan proses

23 Undang-undang Nomor 25 tahun 2007, op.cit., Pasal 32 Angka 4.

24 Abdulkadir Muhammad, Hukum Perikatan, (Bandung: PT. Citra Aditya Bakti, 2006), hlm. 87. 
tawar menawar dalam hal isi perjanjian kredit tersebut.

Dalam segi akses kembali atas kerugian materiil yang disebabkan oleh kredit macet, upaya penanggulangan dilakukan melalui hak tanggungan yang dibebankan pada jaminan kredit yang diberikan oleh debitor. Pemberian limit kredit dilakukan dengan memperhitungkan nilai likuiditas jaminan yaitu sebesar 70\% (tujuh puluh persen) dari nilai pasar, serta melakukan penilaian terhadap kualitas jaminan yang diberikan dengan hanya menerima jaminan berupa tanah dan bangunan, sehingga apabila terjadi kredit macet dengan debitor penanam modal asing, maka nilai jaminan tetap dapat mengcover dari limit kredit yang diberikan sehingga Bank Maspion dapat terhindar dari kerugian.

Nilai Hak tanggungan yang terpasang sebesar $120 \%$ (seratus dua puluh persen) juga merupakan langkah pencegahan atas kemungkinan kerugian yang dapat terjadi dengan memperhitungkan biaya-biaya lain yang timbul dalam proses penyelesaian kredit macet tersebut.

Berbagai langkah-langkah yang dilakukan Bank Maspion dalam melindungi Bank dari kredit macet dengan debitor penanam modal asing tersebut dilakukan secara internal mengingat belum adanya aturan yang jelas mengenai perlindungan hukum terhadap Bank bila terjadi kredit macet dengan debitor penanam modal asing, sehingga upaya perlindungan terhadap Bank lebih difokuskan kepada isi perjanjian kredit dan hak tanggungan merupakan unsur terpenting dalam upaya Bank Maspion untuk menyelesaikan kredit macet dengan debitor penanam modal asing, hal ini juga dilakukan oleh sebagian besar industri perbankan di Indonesia.

Perlindungan Hukum yang merupakan pekerjaan hukum adalah lebih dari hanya logis rasional, melainkan sesuatu yang menuntut kreativitas dari para pelakunya sehingga hukum memperoleh tempatnya ${ }^{25}$. Dalam hal perlindungan hukum terhadap Bank dari kredit macet debitor penanam modal asing, standar baku perjanjian kredit serta hak tanggungan merupakan bentuk kreativitas yang dilakukan oleh industri keuangan pada umumnya.

\section{Simpulan}

Berdasarkan pembahasan yang di angkat dalam jurnal ini, dapat diambil suatu kesimpulan, yaitu:

1. Faktor terjadinya kredit macet selalu diawali dengan tidak dipenuhinya kewajiban oleh Debitor (wanprestasi). Bentuk wanprestasi yang biasanya terjadi berupa tidak dipenuhinya kewajiban pembayaran angsuran baik pokok angsuran maupun bunga pinjaman sehingga apa yang menjadi hak Bank selaku Kreditor tidak terpenuhi, hal ini membuat Bank berupaya meminta pertanggungjawaban dari Debitor untuk 
dapat mengakses kembali hak-haknya yang hilang. Faktor terjadinya kredit macet dapat disebabkan oleh 2 (dua) faktor yaitu faktor internal dan faktor eksternal. Pada debitor PT. Bintang Mas Asia penyebab terjadinya kredit macet disebabkan oleh faktor eksternal yaitu tekanan persaingan usaha, tingginya persaingan di bidang perdagangan alas kaki menjadikan PT. Bintang Mas Asia harus mengurangi keuntungan perusahaan ditambah minimnya angka penjualan akibat lesunya sektor ekonomi Indonesia akhir-akhir ini menyebabkan hal buruk bagi arus kas usaha yang berdampak pada gagalnya kewajiban membayar angsuran kepada Bank.

2. Resiko Bank bila terjadi kredit macet atas debitor penanam modal asing sangatlah besar, kredit macet akan mempengaruhi penilaian terhadap tingkat kesehatan suatu Bank. Batas ambang maksimum untuk kredit bermasalah bagi sebuah adalah lebih dari 5\% (lima persen) dari total kredit. Tingkat kesehatan Bank akan berpengaruh pada bisnis Bank yaitu berupa tingkat kepercayaan masyarakat untuk menyimpan dananya di Bank tersebut, disamping risiko lainnya berupa tuntutan hukum serta kerugian materiil yang dapat disebabkan oleh kredit macet.

3. Perlindungan hukum terhadap Bank bila terjadi kredit macet pada kredit yang disalurkan pada penanam modal yang dilakukan oleh industri perbankan selaku kreditor pada dasarnya tidak memiliki keseragaman, namun terdapat kemiripan seperti pada Bank Maspion selaku kreditor terhadap PT. Bintang Mas Asia selaku debitor penanam modal asing yang mengalami kredit macet, perlindungan hukum dilakukan melalui perjanjian kredit yang dibuat secara baku atau lebih dikenal dengan istilah standard contract dan dibuat secara notariil serta pemasangan hak tanggungan pada jaminan kredit yang diserahkan, titel eksekutorial pada Hak Tanggungan yang dijamin oleh Undang-Undang dianggap cukup dapat melindungi industri perbankan untuk mengakses kembali haknya yang hilang. 


\section{DAFTAR PUSTAKA}

\section{Buku}

Abdulkadir, Muhammad. Hukum Perikatan. Bandung: Citra Aditya Bakti, 2006.

Banker Association for Risk Management, dan Lembaga Sertifikasi Profesi

Hadjon, Phillipus M. Perlindungan Hukum Bagi Rakyat Indonesia. Surabaya: Bina Ilmu, 1987.

Ilmar, Aminudin. Hukum Penanaman Modal di Indonesia. Jakarta: Kencana, 2010.

Perbankan. Modul Uji Kompetensi Profesi Bankir Bidang Manajemen Resiko Level 1-edisi 4. Jakarta: Banker Association For Risk Managemen, 2013.

Pratama, Rahardja dan Manurung Mandala. Suatu Pengantar Teori Ekonomi Makro. Jakarta: Lembaga Penerbit Fakultas Ekonomi Universitas Indonesia, 2014. Safa'at, Rachmad. Ilmu Hukum Di Tengah Arus Perubahan. Malang: Surya Pena Gemilang, 2016.

\section{Peraturan Perundang-undangan}

Undang-Undang Republik Indonesia Nomor 4 Tahun 1996 tentang Hak Tangggungan
Atas Tanah Beserta Benda-Benda Yang Berkaitan Dengan Tanah.

Undang-undang Nomor 23 tahun 1999 tentang Bank Indonesia.

Undang-undang Nomor 25 Tahun 2005 tentang Penanaman Modal.

Peraturan Bank Indonesia Nomor 3/10/ PBI/2001 tentang Penerapan Prinsip Mengenal Nasabah (Know Your Customer Principles).

Peraturan Bank Indonesia Nomor 3/25/ PBI/2001 tentang Penetapan Status Bank Dan Penyerahan Bank Kepada Badan Penyehatan Perbankan Nasional.

Peraturan Bank Indonesia Nomor 5/8/ PBI Tahun 2003 tentang Penerapan Manajemen Resiko Bagi Bank Umum.

Peraturan Bank Indonesia Nomor 13/1/ PBI/2011 tentang Penilaian Tingkat Kesehatan Bank Umum.

Peraturan Bank Indonesia Nomor 14/15/ PBI/2012 tentang Penilaian Kualitas Aset Bank Umum. 